\title{
POLICY IMPLEMENTATION OF INTERNATIONAL UNDERGRADUATE PROGRAM IN INDONESIA'S HIGHER EDUCATION SYSTEM: A STUDY AT FACULTY OF ECONOMICS AND BUSINESS UNIVERSITY OF BRAWIJAYA
}

\author{
Wardani Malisa Cory*, Santoso Bambang, Hariswanto Alfi \\ Faculty of Administrative Science, University of Brawijaya, Indonesia \\ *E-mail: lovegirlpower2@gmail.com
}

\begin{abstract}
This study aims to find out the success of policy implementation of international undergraduate program at FEB-UB by analyzing the influencing factors based on the theory of policy implementation Edward III, among others communication factor, resource, disposition and bureaucratic structure. This was qualitative descriptive research (case studies). The data were collected from interview, observation, and document study. This study was conducted at FEB-UB. The result of the study shows that: 1) Communication happens along this time both between Faculty and students mostly uses indirect communication since it feels more effective and efficient. However, direct communication is a routine activity at the first year by inviting parents. 2) Resource, support of international undergraduate program policy's executing agent at FEB-UB both human resources, budgetary resources, information and authority and facility and infrastructure is sufficient. But then there are several deficiencies like an amount of human resources needs to be added. 3) Disposition is measured from the policy's executing agent and student level of obedience. Policy's executing agent is measured to have been good. In line with the policy's executing agent, students' obedience is also measured to be good since their support in the policy of international undergraduate program. 4) Bureaucratic structures are measured from the availability of internal Standard Operating procedure (SOP) connected to the policy implementation of international undergraduate program at FEB-UB and its fragmentation. FEB-UB's international program unit has a complete SOP that rules plots of service performance at international undergraduate program. Coupled with the pattern of work relationship and distribution of duties (fragmentation), FEB-UB's international undergraduate program unit has good pattern of work relationship and is suitable for its respective field.
\end{abstract}

\section{KEY WORDS}

Policy implementation, international undergraduate program, higher education.

Education is a mandatory for every human being in the world. Since through education people will be able to face problem and challenge they will face. The big challenge in life also influences the level of knowledge which has to be owned by human being.

Indonesia is one of the countries with much more capacity of human resources. But in managing its human resource, Indonesia is still much more left behind from the neighboring countries like Malaysia, Thailand, Philippines, and other countries. This causes by the educational level in Indonesia which is low and inadequate facility so affecting on the low quality labor, jobless increases, productivity decreases, and competitiveness is low to be able to face competition between both local and foreign labor. For that reason it needs to improve the standard of education for all Indonesian.

Law no 20/2003 article 1 paragraph 1 on the national education system states that education is a conscious effort by human being to increase their potential through learning process. Education is a process that helps to form those receiving education to be a human resources having professional ability, productive, creative, independent, excellent and having noble character as the nation's asset in succeeding national development. Law on the National Education System (N0.20/2003)

University as the highest educational institution is expected to contribute as provider of educated and quality human resources. University in Indonesia as one of the drives of the 
national development responsible to produce graduate who have deep and wide viewpoint and skill both local, national, and international as well as able to compete with graduate from foreign university.

In order to increase Indonesia's university competitiveness with foreign university, we need to pay attention quality improvement of university seriously. One of the ways to improve the quality of university quickly is through building cooperation with foreign universities having good reputation. Through the cooperation with foreign universities, universities in Indonesia can influence each other in several things, among others the improvement of academic talent quality, student, prestige, research, and another resource.

International undergraduate program is part of cooperation with foreign universities in term of improving and developing the university to face the challenge of global education and create an individual who really have quality and able to compete globally.

Definition of international class program at university refers to the decree of the Directorate General of Higher Education (Ditjen Dikti), Ministry of National Education No.61/DIKTI/Kep/2000 that the form of cooperation of Indonesia's universities with foreign university or other institutions is at one educational activity unit namely, (1) twinning, (2) lecture and student exchange to hold academic activity, (3) resource utilization in the implementation of academicals activity, (4) credit transfer.

University of Brawijaya is one of the leading universities in Indonesia established in 1963 with its main campus located in Malang, East Java. In order to achieve World Class University status and coupled with its vision and mission as internationally-top university and competitive ASEAN university, University of Brawijaya tries to perform educational internalization by integrating international component into the purpose, function or educational explanation, then the step to do is opening international class program.

International class program at University of Brawijaya started by Faculty of Medicine in 2006 then followed by Faculty of Administrative Science and Faculty of Economics and Business in 2007. International class program owned by University of Brawijaya succeeds to improve the number of foreign student and cooperation with foreign universities.

International undergraduate program at several Faculties in University of Brawijaya has been running since 2006 but the others who initially seriously implement this program are now known to no longer exist. Faculty of Economics and Business University of Brawijaya (FEB-UB) is one of the faculties that are still consistent until today to run international undergraduate program and continuously develop it by opening the program at its departments.

This study aims to describe and analyze the success of policy implementation of international undergraduate program at FEB-UB by analyzing the influencing factors based on the theory of policy implementation Edward III, among others communication factor, resource, disposition and bureaucratic structure.

\section{METHODS OF RESEARCH}

This was descriptive qualitative research (case study). It focuses to 1) describe and analyze policy implementation of international undergraduate program at FEB-UB based on the perspective Edward III, i.e., (a) Communication performed at policy implementation of international class program at FEB-UB; (b) Human resources performing implementation process of international class program, both human resources, budgetary resources, information and authority and facilities and infrastructure; (c) Disposition in performing international class program consists of understanding of performance towards policy (policy's goal), referrals and respond (readiness and commitment) covers to acceptance and respond from executing agent; (d) bureaucratic structure of international class program covers to: organizational chart of program performance, setting work mechanism and rule or executing agent's obedience to the SOP fixed.

This study was conducted at University of Brawijaya, Malang, East Java Province, while the site of the research is at Faculty of Economics and Business. Data collection method uses case study approach from Robert K.Yin (Kusmarni, 2011 p.103) namely, 
documentation, archives recording, interview, direct observation, participant observation and a set of physical or cultural with interview, observation, and documentation procedural. Research instrument is the researchers itself who goes directly into the field to collect data by holding an unstructured observation or interview by using note book. Data analysis used in this study is a case study conducted twice: firstly was analysis at field during the data collection (formulating idea and data review) and secondly after the data collected (data interpreting, data presentation and searching of literature) by Robert K.Yin (Kusmarni, 2011 p.118)

\section{RESULTS AND DISCUSSION}

Policy implementation of international undergraduate program at FEB-UB uses a model from the theory proposed by Edward III (1984:9) in which the success of policy implementation can be influenced by four critical factors, i.e. communication, resource, disposition and bureaucratic structure. Those four variables have indicator which can influence the success of policy implementation.

The first factor is communication from the policy implementation of international undergraduate program at FEB-UB namely, a). Information transformation (transmission), in term of policy implementation of international undergraduate program of FEB-UB, it is a form of delivering or sending information from the faculty then forwarded to the policy's executing agent which is the unit of international program (UPI) as the administrator of international undergraduate program of FEB-UB and the last is forwarded to students and public community that need the information like students and their parents. According to the result of interview conducted to the data resources, it is known that policy communication is directly performed by giving socialization. This is done to give information to students. Socialization is performed twice by implementing officer of international undergraduate program of FEB$\mathrm{UB}$, firstly is conducted with the applicant of international class during interview session and secondly is inviting parents at the first semester. Transformation desires information to not only delivers to the policy's executing agent but also target group and involved party (Purwanto, 2012). While transmission process from faculty as the policy maker to the policy's executing agent is executed by conducting monthly coordinating meeting. b) Clarity of information, communication accepted by policy's executing agencies has to be clear and easy to understand to facilitate in taking action (Agustino, 2006 h.150). Based on the result of field observation, clarity of policy reporting of international undergraduate program is in addition to direct socialization to students and parents, it also efficient enough to utilize printed media like academic guide book or electronic media. c) Consistency of information. Based on the interview and field observation, information delivery on the policy of international undergraduate program has been consistently performed; socialization is performed routinely by the management unit of international undergraduate program. Implementing officer is very active to use media to deliver the information.

The second factor is the condition of supporting resources. Resource here is related to the whole sources that can be used to support the success of policy implementation. This covers; a) human resources (staff), policy implementation really needs support from the availability of human resources which its quality and quantity is sufficient. Human resources quality is related to the skill, dedication, professionalism, and competence in its field. Based on the researchers' observation, educational background of international undergraduate program's staff at FEB-UB is mostly doctorate degree. Almost all of staff is foreign universities graduate while the administration staff has educational background in English. In addition to have English command, they are demanded to have professionalism. Such a demand makes faculty performs an effort in order to improve the quality of human resources. As what have been stated by administration officer of the unit of international undergraduate program FEB-UB that there has been training related to the program held by FEB. If seen from the quality side, human resources have been competent enough to execute the program. While from the quantity side, the number of staff is not sufficient enough yet so they have a double job. This has influence over the smooth of administration process and the 
quality of service to the students. b) Budgetary, in relation to the financial resources of international undergraduate program at FEB-UB, it has been budgeted at department budget by the faculty. For that reason, it can be said that the aspect of budgetary resources of international undergraduate program gets adequate budgetary support. c) Information and authority, based on the field observation, then it is known that information given by the stakeholder has been performed and obeyed by policy's implementing agencies and is suitable with the employment contract of implementing agencies to the stakeholder. Such information is also important to bring someone back to consciousness involved in the implementation so they will implement and comply what become their task and obligation. On the other hand, the form of authority given to the implementing agencies of international undergraduate program FEB-UB can be seen from the Dean's decree No $046 / J 10.1 .12 / S K / 2009$ on the establishing of international undergraduate program officer of FEB-UB. d) Infrastructure and facility is one of the influencing factors in the policy implementation. The result of observation conducted by the researcher shows that facilities and infrastructure is a complimentary factor in the implementation of international undergraduate program. Facilities provided to this class is optimal enough and able to prop all the learning process up like the availability of a standard class completed with LCD, tutorial room and representative computer laboratory in the classroom.

Quantity and quality of media during the learning process is also providing optimally like digital library and the unit of business center and bank counter. Procurement of sufficient facility like mentioned above will support success of implementation of a program or policy.

The third factor is disposition, according to Eddward III in Winarno (2005 p.142) tendencies or disposition is one of the factors having important consequences for an effective implementation policy. Attitude and commitment from the policy's implementing agencies is a must they should have to be able to reach policy's goal expected. In relation to the implementation of international undergraduate program at university of Brawijaya, FEB's respond as the executing agent generally support the implementation of international undergraduate program at University of Brawijaya and has willingness and desire to execute this policy seriously. In performing the implementation of international undergraduate program, FEB establishes a special unit of management to manage international undergraduate program which is UPI. Having been seen from the students' point of view, international undergraduate program which also plays as an important executing agent in the policy performance, it is known that his/her attitude has been good. UPI or students really support this program implemented at FEB-UB.

The fourth factor that influences the success of public policy implementation is bureaucratic structure. According to Edwards III in Winarno (2005 p.150) there are two main indicators of bureaucracy:

a) SOP, according to Insani (2010 p.11) standard operational procedure is a document containing a series of standardized written instruction on various processes of administrative arrangements containing ways of doing work, regulations that contain internal coordination of the international undergraduate program unit as actors who play a role in activities. Service standards are used as guidelines of implementation and assessment guidance to provide quality, fast, easy, affordable and measurable services. SOP becomes the guideline for every executing agent in acting so that in the implementation of policy does not deviate from policy objectives and targets. In addition, by using SOPs, implementers can optimize the time available and can serve to uniform the actions of officials within a complex and widespread organization, thereby generating great flexibility and great similarity in the application of rules. Based on the observation and documentation, it is found that the management of International Class Program of Faculty of Economics and Business University of Brawijaya by International Program Unit (UPI) in carrying out its duties and functions has performed its duty in accordance with Standard Operational Procedure (SOP) and vision and mission from the Department. As a value that becomes the tendency of the implementers of International Class Program in FEB-UB in running the duties and functions of each part in achieving organizational goals in accordance with the expertise. Vision and mission for an organization is a bridge between dreams that want to be realized in the future. The existence of a vision- 
mission for an organization to make what it wants to do to be directed. The effort to combine the desire to be achieved by the organization with the aspirations and demands of a dynamic public will make it easier for the organization in carrying out the work and tasks of the organization in accordance with the field or expertise. Implementation of duties and functions, especially for executing officers performed to implement the vision-mission of the organization is an effort to provide satisfaction of service to the community.

b) Fragmentation, according to George C Edward III in Agustino (2006 p.153) that fragmentation is an effort to disseminate the responsibility of activities or work activities to several employees in work units, to facilitate the work and improve service. The implementation of the policy of the International Class Program has been appropriate in the role and duties as well as the coordination between the implementing parties. The distribution of job description is intended to facilitate the implementation of this policy. Even though each policy's implementing officer has their own different duties, but coordination is required between them so that what becomes the objective of the international class program policy can be achieved. In relation to the staff's work culture and work ethic, they have been running this program well and it has been in accordance with the rules set by the faculty. The head of international Program of FEB-UB said that the staffs have implemented a work culture of participative management and work ethic according to the vision and mission which is expected by faculty. For that reason, implementation of the international undergraduate program at FEB-UB has fulfilled the structure in accordance with the theory of Edward III in Nugroho (2012 p.693) which affirms that the appropriateness of bureaucratic organization which turns into the executing agent of public policy implementation becoming the factor supporting the success of one policy. Likewise with the condition of human resources in the implementation of the international undergraduate program of FEB-UB is good enough, the conditions among the officers are also good, especially regarding the infrastructure and facilities and the consciousness of officers' performance in performing tasks that must be oriented to the needs of students, policy's executing agent selected is those who are competent in their field. It is like an idea of Sinambela in Pasoong (2008 p. 211) stating that the quality of service is reflected in transparency by which open and easy service as well as accessible to all parties who need and provided adequately and easily understood.

\section{CONCLUSION}

Communication occurred during this time between the management unit of international undergraduate program and student or parents mostly use indirect communication since it is more effective and efficient. However, direct communication is still a fixed routine. Effective communication in an organization is also performed to support the delivered of policy's goal.

Resource, support of international undergraduate program policy's executing agent at FEB-UB both human resources, budgetary resources, information and authority and facility and infrastructure is sufficient. But then there are several deficiencies like an amount of human resources needs to be added. The lack of executing agent causes load of work increases so that the staff have double job.

Disposition is measured from two aspects, they are policy's executing agent and students level of obedience. Executing agent's obedience is rated to be good since the employment contract between the head of department of international undergraduate program of FEB-UB and the dean as well as supportive attitude to the policy of international undergraduate program at FEB-UB. In line with the policy's executing agent, students' obedience is also measured to be good since their support in the policy of international undergraduate program.

Bureaucratic structures, rated from two aspects, i.e., availability of internal SOP related to the policy implementation of international undergraduate program at FEB-UB and the fragmentation, is a responsibility spread of a policy. FEB-UB's international program unit has a complete SOP that rules plots of service performance at international undergraduate 
program. In relation to the work relationship and distribution of duties, unit of international undergraduate program of FEB-UB has good work relationship pattern and is suitable for respective field.

\section{REFERENCES}

1. Bush, T. \& Coleman, M. (2006). Manajemen Strategis Kepemimpinan Pendidikan. (terj.) Oleh Fahrurozi. Yogyakarta: IRCiSoD.

2. Sam, C.M. \& Sam, T.T. (2013). Kebijakan Pendidikan Era Otonomi Daerah. Jakata: RajaGrafindo Persada

3. Dunn, W.N. (2003). Pengantar Analisis Kebijakan Publik. Second Edition. Yogyakarta: Gadjah Mada University Press.

4. Edwards III, G.C. (1980). Implementing Public Policy. Washington D.C. Congressional Quarterly Inc.

5. Grindle, M.S. (1980). Politics and Policy Implementation in the Third World. Princeton University Press, New Jersey.

6. Haryana, K. (2007). Konsep Sekolah Bertaraf Internasional. Jakarta: Direktorat Pembinaan Sekolah Menengah Pertama.

7. Hosio, J.E. (2007). Kebijakan Publik Desentralisasi. Yogyakarta: Laksbang.

8. Howlett, M. and Ramesh, M. (1995). Studying Public Policy, Policy Cycles and Policy Subsystem. Oxford, Oxford University Press.

9. Hughes, O.E. (1994). Public Administration and Management: An Introduction. London: The Macmillan Press.

10. Krippendorff, K. (1991). Content Analysis: Introduction Its Theory and Methodology. Translated by F. Wajidi, Analisis Isi: Pengantar Teori dan Metodologi. Jakarta: Rajawali.

11. Mazmanian, D.H. and Sabatier, P.A. (1983). Implementation and Public Policy. New York: Herper Collins.

12. Moleong, L.J. (1999). Metodologi Penelitian Kualitatif. Bandung: Remaja.

13. Muhadjir, N. (2006). Kebijakan dan Perencanaan Sosial: Sustainabilitas dalam Social Construc. Yogyakarta: Rake Sarasin.

14. Pasolong, H. (2013). Teori Administrasi Publik. Bandung: Alfabeta

15. Purwanto, B.M. (2009). Internationalization of educations. Presented in Internationalization Workshop on PE program of sporst science faculty Yogyakarta state university.

16. Sjahrir. (1988). Kebijaksanaan Negara: Konsistensi dan Implementasi. Jakarta: LP3ES.

17. Soesilawati, E. (2008). Kebijaksanaan Publik: teori dan aplikasi. Semarang: UNNES Press.

18. Usman, H. (2010). Manajemen Teori, Praktik, dan Riset Pendidikan. Jakarta: PT Bumi Aksara., hal 59

19. Wahab, S.A. (2011). Pengantar Analisis Kebijakan Publik. Malang: UMMPress

20. Winarno, B. (2007). Kebijakan Publik, Teori dan Proses. Yogyakarta: Media Presindo. 